\title{
Effect of Energy Market Globalization over Power Sector of GCC Region: A Short Review
}

\author{
Armaghan Ahmad ${ }^{1}$, Muhammad Babar ${ }^{1,2}$ \\ ${ }^{1}$ Institute of Industrial and Manufacturing Engineering, Pakistan Navy Engineering College, National University of Science and \\ Technology, Karachi, Pakistan; ${ }^{2}$ Department of Electrical Engineering, College of Engineering, King Saud University, Riyadh, \\ KSA. \\ Email: armaghan33@gmail.com, engr.mbabar@gmail.com,mababr@ksu.edu.sa
}

Received November $13^{\text {th }}, 2012$; revised March $1^{\text {st }}$, 2013; accepted March $9^{\text {th }}, 2013$

Copyright (c) 2013 Armaghan Ahmad, Muhammad Babar. This is an open access article distributed under the Creative Commons Attribution License, which permits unrestricted use, distribution, and reproduction in any medium, provided the original work is properly cited.

\begin{abstract}
Globalization of energy market in GCC countries is deepening not only through free-flowing international trade but also through foreign investment, market-driven domestic economies and industrialization. GCC nations are transforming their energy industry and market around the world which is promising their economic efficiency and technology development. Nevertheless, this open energy market across the world has raised a question about energy security and power demand. This energy market globalization has pushed the GCC Nations to pay attention to the control of supply and demand of power. Interconnection of power network between the GCC Region is optimistic pace to secure the future anticipated power fallouts. And also installation of Renewable Energy projects will support GCC to accommodate their increasing power demand. This paper discusses about how the energy market globalization has affected the power supply and demand of GCC nations, their concerns and recent progress towards its resolution.
\end{abstract}

Keywords: Globalization; Energy Market; Power Sector; GCC; Renewable Energies; Grid Interconnection Network

\section{Introduction}

The Globalization of energy market is not a new phenomenon. For centuries, countries have been trading energy internationally. But during last few decades, uneven and rapid growth in world population and demand of energy and power has raised some wrenching challenges to world's policy makers and security planners.

Table 1 illustrates the world energy consumption since 2008 and expected consumption till 2035. It is inferred from IEO Report that the world net electricity generation rises by $87 \%$ from 18.8 trillion $\mathrm{kWh}$ in 2007 to 25.0 trillion $\mathrm{kWh}$ in 2020 and 35.2 trillion $\mathrm{kWh}$ in 2035. In OECD countries, where electricity markets patterns are matured but growth of electricity demand is slower than in non-OECD countries like GCC countries, where a large amount of potential demand remains unmet. World proved oil reserve in 2010 were sufficient to meet 46.2 years of global production, down slightly from the 2009 $\mathrm{R} / \mathrm{P}$ ratio because a large increase in world production, global proved reserves rose slightly last year. The Middle Eastern reserve over production is decreasing. World gas reserves proved in 2010 were sufficient to meet 58.6 years of global production. R/P ratios decline for each region, driven by rising production and demand. The Middle East once again had the highest regional R/P ratio as shown in Figure 1 [1].

However, IEO reported that from 2007 to 2035, the world renewable energy use for electricity generation

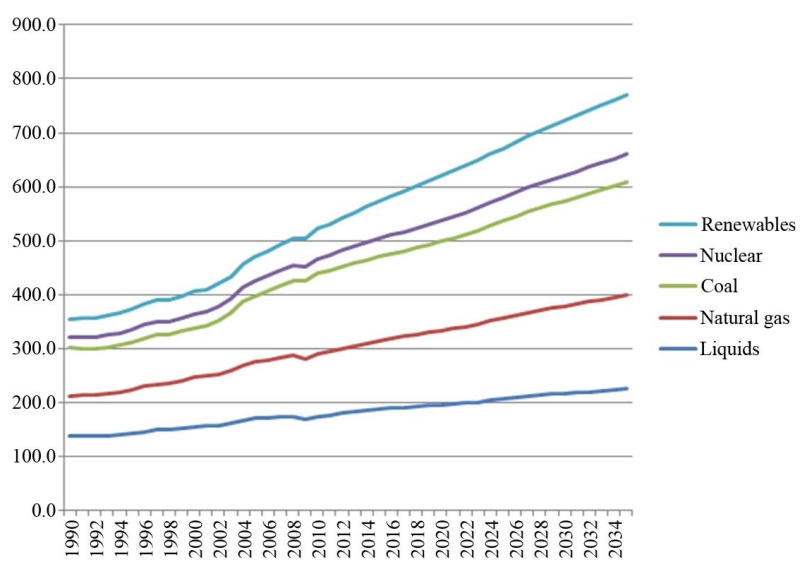

Figure 1. IEO report: The world net electricity generation rises by renewables. 
Table 1. World energy consumption.

\begin{tabular}{cccccccc}
\hline Years & Liquids & Other renewables & Nuclear & Hydroelectricity & Natural gas & Coal & Total \\
\hline 2008 & 1.0 & 0.5 & 2.6 & 3.1 & 4.2 & 7.7 & 19.1 \\
2015 & 0.9 & 1.3 & 3.2 & 3.8 & 4.9 & 8.5 & 22.7 \\
2020 & 0.9 & 1.8 & 3.7 & 4.5 & 5.6 & 8.9 & 25.5 \\
2025 & 0.9 & 2.1 & 4.2 & 4.8 & 6.5 & 10.2 & 28.7 \\
2030 & 0.8 & 2.4 & 4.5 & 5.2 & 7.5 & 11.5 & 31.9 \\
2035 & 0.8 & 2.6 & 4.9 & 5.6 & & & 12.9 \\
\hline
\end{tabular}

grows by an average of $3.0 \%$ per year, and the renewable share of world electricity generation increases from $18 \%$ in 2007 to 23\% in 2035 as shown in Table 1. Coal-fired generation increases by an annual average of $2.3 \%$, making coal the second fastest-growing source for electricity generation. Generation from natural gas increases by $2.1 \%$ per year and nuclear power increases by $2.0 \%$ per year as shown on Figure 2 [2].

Recently, energy demand and supply issues have made the nations of the world much more dependent upon each other for their welfare and security. Energy consuming nations need ever-growing quantities of oil, gas and coal from abroad while energy producing nations need evergrowing amounts of foreign capital to develop the facilities necessary to extract more resources.

Meanwhile, both sets of countries must build and maintain huge amounts of infrastructure to process, generate, transport, and deliver the energy according to their citizens and industries requirements. Under these circumstances, the actions of consuming nations could affect the ability of producing nations to achieve their goals, and vice versa. According to IEA, energy demand will grow by two-thirds between 2001 and 2030 while key factors being fuel for vehicles and electricity for home use [3].

The major oil producers i.e. GCC region has been experiencing major economic growth and providing financial incentives to its citizens. On contrary, fast population growth and vast commercialization and industrialization is leading high demand of energy. This issue has pulled the GCC nations to think about their power market and invest more on alternatives so as to reduce or stabilize their power consumption.

The paper discusses the effect over power sector of GCC countries after this vast energy globalization process in Section 1. Section 2 discusses about the recent progress of GCC countries toward the stabilization of their power sectors. Section 3 discusses about the concerns and insecurities which are currently being faced by the nations. Section 4 concludes the discussion.

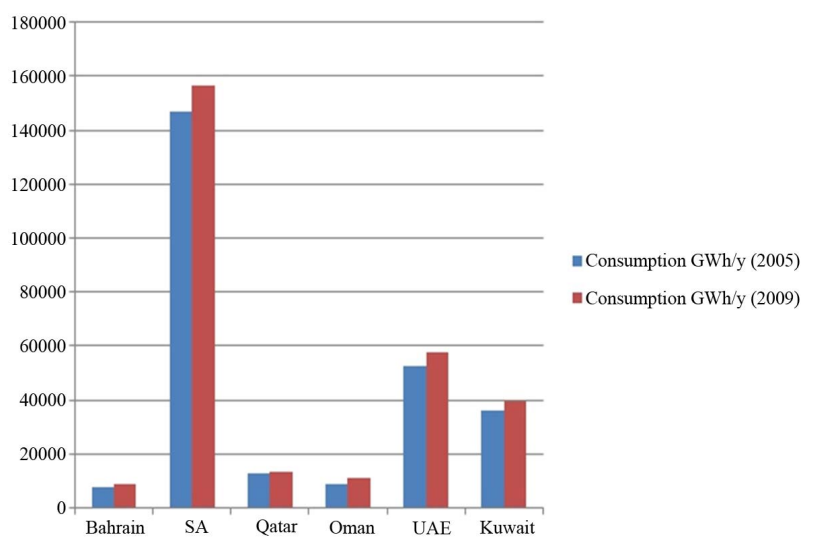

Figure 2. IEO: Increase in the GCC renewable energy use for electricity generation.

\section{Energy Globalization}

The total demand for electrical power consumption in the GCC countries is expected to triple over the next 25 years. Moreover, the projected statistics states that electricity consumption over population is increasing rapidly. Since GCC nations are producing most of their electricity from oil and gas, therefore, upcoming challenge is to cater their own local demand which is also increasing rapidly as well as keep their economies stable because the economy of GCC region is primarily based on international trading of oil and gas.

With installed capacity of $152 \mathrm{GW}$, the Middle East represents 3.5\% of global electricity generation with $97 \%$ thermal generation. Power demand growth has been minus $6 \%$ year-on-year for the last decade relative to minus 2\%/annum for the United States and Europe.

The analysis shows that the UAE power market is tight in the peak demand months in summer for next two years. And they have only a 6\% surplus available in the worstcase scenario. The UAE accounts for $10 \%$ that is 70.8 TWh of the total Middle East market. Saudi Arabia is the second largest power market in the Middle East with 27.5/annum that is around 190.5 TWh market share [1] and installed capacity of more than 50 GW. 
Electricity demand growth in Saudi Arabia has averaged $6 \%$ year-on-year for the last five years, which is mainly supported by new industrial infrastructure and water projects. Kuwait accounts for $6.5 \%$ that is 45.1 TWh of the Middle East power market. Kuwait forecast demand growth on average at 5\%/annum with peak load availability growth on average at 6\%/annum to 2015 . Qatar accounts for $2.4 \%$ that is 16.3 TWh of the total Middle East power while electricity demand growth in Qatar has averaged eight per cent per annum for the last five years [4]. Table 2 shows the consumption of power by GCC nations during year 2005 and 2009.

Moreover, IMF reported in it's Economist Intelligence Unit long-term forecasts. That the rate of increase in electricity consumption in GCC countries from 2005 to 2009 was $8.87 \%$ (largest rate was in Oman, 22.6\%, and least in SA, 6.3\%) with average per person of 1149 $\mathrm{W}$-which is 3.9 times the world average, 0.8 of USA average, 4.2 of China average and 1.7 of EU average in 2009. The GCC countries produce electric power and consume electricity it at a very high rate as shown in Figure 3. Thus, CIA World Fact Book in 2009 reported-

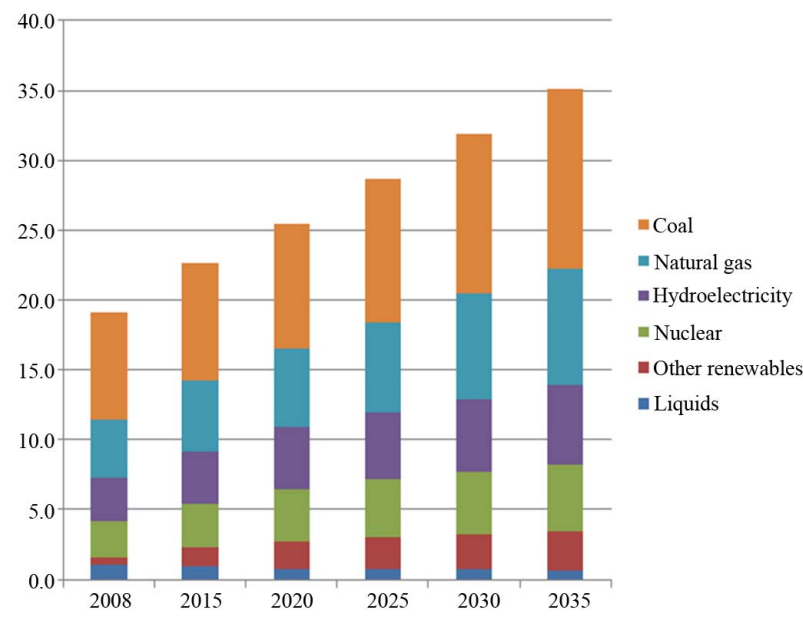

Figure 3. Sources: IMF; individual country statistical agencies (historical data); Economist intelligence unit long-term forecasts.
Saudi Arabia, SA, is ranked worldwide 16 in electricity consumption (156,800 GWh), Kuwait is ranked 53 (39,540 GWh), United Arab Emirate, UAE, is ranked 41 (57,880 GWh), Oman is ranked 80 (11,190 GWh), Qatar is ranked $76(13,190 \mathrm{GWh})$ and Bahrain is ranked 88 (8742 GWh) [5].

Realizing this imminent challenge by energy market over power sector, GCC countries have embarked on a plan to restructure and privatize their power sectors to meet such demand. Thus governments are encouraging the private sector to invest in this lucrative industry. The six GCC countries are also electrically interconnected by GCC interconnection grid, which will supply electricity during emergencies, reduce generation reserves for the countries, improve efficiency and provide a basis for electrical power exchange. GCC governments are also getting very active in deployment of Renewable Energies.

\section{Recent Progress in Energy Market of GCC}

Before 1990 all the power utilities in GCC were government owned and vertically integrated. Governments of GCC Region now accepted the benefits of private sector participation in the power sector. So, Oman, U.A.E., Qatar and Saudi Arabia have passed the legislation allowing the construction and operation of power plants by private sectors. Now, GCC countries are in the middle of dividing their power sector into separate generation, transmission and distribution segments. By this initiative, GCC is providing an opportunity for private sectors to invest their capital in energy market. Researchers have demonstrated that the interconnection among the GCC members is technically feasible as well as viable. The subsequent research finally lead to the formal establishment of GCC Interconnection Authority in 2001 by the Royal Decree from the Six GCC Countries. Figure 4 shows the interconnection project of power grid between the six GCC countries.

This interconnection of Energy Grid among the GCC countries would provide the opportunity for trading elec-

Table 2. The electricity consumption in the GCC countries in 2005 and 2009 (in $\mathbf{M W} \cdot \mathbf{h} / \mathbf{y}$ ).

\begin{tabular}{cccccc}
\hline Country & Consumption GW·h/y (2005) & Consumption GW·h/y (2009) & Population (2005) & W/person (2005) & Rate \\
\hline Bahrain & 7614 & 8742 & 727,000 & 1195 & 12.9 \\
SA & 146,900 & 156,800 & $24,573,000$ & 682 & 6.3 \\
Qatar & 12,520 & 13,190 & 813,000 & 1757 & 3.1 \\
Oman & 8661 & 11,190 & $2,567,000$ & 385 & 22.6 \\
UAE & 52,620 & 57,880 & $4,500,000$ & 1335 & 9.1 \\
Kuwait & 36,280 & 39,540 & $2,687,000$ & 1540 & 8.2 \\
Total GCC & 264,595 & 287,342 & $35,867,000$ & 1149 & 8.87 \\
\hline
\end{tabular}




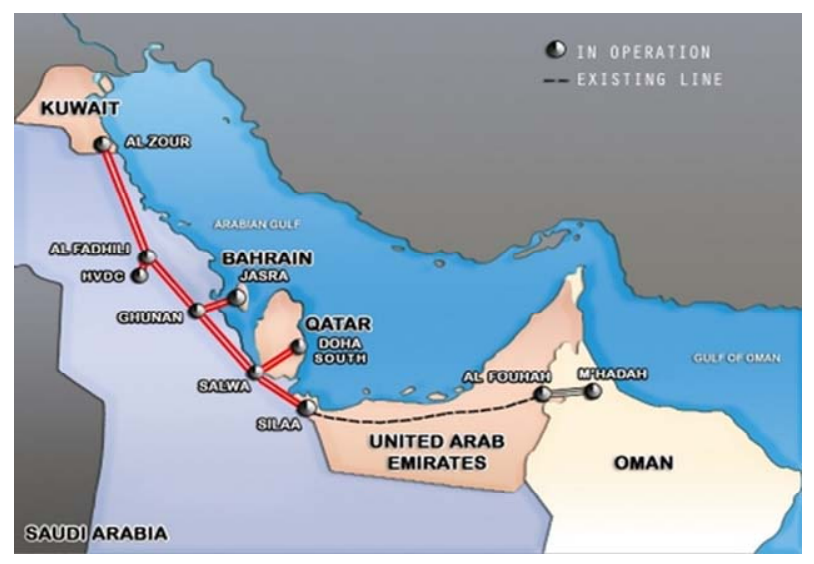

Figure 4. GCC power grid interconnection project [10].

tricity between the member countries as well as eventually trading outside the GCC. Due to reserve sharing, lower capacity systems are installed which will supply the power with the similar reliability factor. It permits installation of efficient generating divisions, enable systems to share operating (spinning) reserves so that each system can carry less spinning reserve, lowers the total operating costs, take support from neighboring structures to cope with unforeseen contingencies or multiple outages [6-9].

Because of energy market globalization, renewable energies are now capturing significance in the power policies of entire world. Due to rising international and domestic energy demand, GCC region has started thinking sincerely in this domain and already has initiated many pilot projects. Researchers believe that Renewable energies can eventually support GCC's oil and gas exports. Energy created from renewables could gradually substitute oil as the GCC's major export item. A necessary precondition for this would be a wholehearted embrace of the renewable energy trend by the GCC countries and their development into technological leaders in the field. Renewable energy generation would not only replace the power energy production by oil and gas, but the GCC economy will become more stable in tight global energy markets $[10,11]$.

Saudi Arabia took initiatives in solar power projects in the 1980s. Energy Research Institute (ERI) of King Abdul-Aziz City for Science and Technology (KACST) has conducted research in renewable energies and energy efficiency. KACST published the Solar Energy Atlas and the Saudi Arabian Wind Energy Atlas for Saudi Arabia in 1983 and 1986 respectively in cooperation with King Fahd University for Petroleum and Minerals in Dhahran. Solar Energy Research American-Saudi (SOLERAS) and Hydrogen from Solar Energy (HYSOLAR) are two topline international agreements made by Saudi Arabia to promote Solar Energy [12-16].
SOLERAS was \$100 Million project which is completed in 1997 and supplying energy to Al-Jubaila and Al-Uyaina. It was one of the largest PV systems worldwide at that time (350 kW). Other projects included a PV system to power a desalination plant in Jeddah, solar assisted technology to fend off corrosion in underground pipelines, solar powered greenhouses and installing the heating system of a school in Tabuk. KACST has implemented other solar power projects as well like solar cooling, PV powered highway lighting and use of solar dryers in agriculture. But these initiatives remained pilot projects and were not developed further. They faced deteriorating economics as oil prices plunged in the second half of the 1980s and remained low till the end of 1990s. But the recent surge in fossil fuel prices has increased the interest of GCC countries in renewable energies [17-21].

In Oman, the Authority for Electricity Regulation has outlined a road map for the development of renewable energy resources. The establishment of large-scale solar thermal plants and a $750 \mathrm{MW}$ wind farm in the south of the country rank prominently among the proposed projects. However, the government is paying attention to the development of an appropriate policy framework and institutions to administer clean development mechanisms (CDMs) and assist renewable energy investment [22]. Oman and Bahrain has some experience with solar powered reverse osmosis units for desalination and photovoltaic systems or wind power for water pumping and electricity generation [23].

In 2004, The Kuwait Petroleum Company (KPC) has allocated \$100 million for new energy technologies. However, the focus is over more environment-friendly use of fossil fuels by fuel cell technology, carbon sequestration and oil gasification, with the aim of taking advantage of the Clean Development Mechanism (CDM) of the Kyoto Protocol [24].

Abu Dhabi's Masdar initiative is the most significant initiative for renewable energy in the GCC. It seems that the government of Abu Dhabi has taken on the Saudi initiatives of the 1980s on a much larger scale, in order to take advantage of the technological progress and the improved economics that have taken place in renewable energy [25-27].

Using renewable energy in the GCC countries will help in prolonging the fossil fuel reserves for an extended period of time as well as reducing the carbon foot print in the region, which is average 20 tons per capita with highest in UAE (nearly 60 ton per capita) to the lowest in Saudi Arabia (nearly 18 ton per Capita). This will also have an impact in worldwide use of petroleum which is 80 million barrels daily at present [28].

These renewable energy sources with the backup of fossil fuel power plants can power the connected grid of GCC with the new levels of security and reliability at 
low operational cost. These fossil fuel plants are also necessary to power the system with reliability in the periods of low sun radiation and wind. By the employment of hybrid system, the GCC countries will contribute towards the green future with very small carbon footprint. Economy will grow as well due to the major export of oil and petroleum products that is sold to the world at more than 20 times the price it is sold to local power producers [29].

\section{Concern}

Earlier energy security has never been considered as an issue in a world of integrated energy markets, but recently public concern and insecurity regarding energy is heightened in the entire world as the gasoline prices rose in the past few years. Globalization of Energy is affecting the GCC Countries as they must extract large quantities of energy to meet foreign and domestic demand, and develop the internal infrastructure to facilitate growing domestic power demand. So, GCC nations spurn capital needed to finance more production of Energy and Power. Energy market globalization might also cause potential political fallout of power in developing and transitional economies like GCC Region.

As markets and infrastructure are connected across national borders, fuel substitution and economic benefits accrue in GCC region. But at the same time, new vulnerabilities are created like exploration and production are curtailed by conflicts creating security risks. International conflicts jeopardize the security of power grid and routes. Moreover, International rivalries affect the political popularity of relying on power from certain regions or countries. Energy experts see global warming as a major threat and they believe that there will be negative impacts on power production and energy security.

Global energy market integration can create a political backlash that threatens the security of neighbors who buy energy from them or import it through their territories. Like in Northeast Asia, intense discussions are now under way about cooperation in pipelines and high-voltage transmission lines extending from Russia into China. According to some estimates, Eastern Russia could supply half of Northeast Asia's natural gas needs by 2020. So, strong co-operative and joint planning is required by all six GCC governments as well as private sector organizations so as to anticipate and mitigate risks involved in energy security for the successful implementation of projects for power and energy security [30].

Extrapolating 20 years ahead based on consensus, supply-and-demand projections that show sharp increases in world energy requirements, a number of energy-related issues are likely to generate new types of problems and unintended consequences associated with deepening globalization. For safety, environmental, and non-prolif- eration reasons, advanced technology cooperation in energy among GCC nations is essential. In addition, governments will need to work to strengthen non-proliferation norms and to build cooperation in material protecttion, accounting, and export controls. Other forms of cooperation are also needed to make the most of new technologies that are coming on stream. Regulatory barriers as well as established business practices might present obstacles to the application of new equipment and systems [31,32]. Earlier discussion over progress of GCC nation in power and energy sector elucidates that six governments are very concern and taking all possible paces regarding this uneven power sector reform.

\section{Conclusions}

In closing, Globalization in Energy Market has changed the energy philosophy of Middle Eastern countries. This uneven increase in energy consumption has negatively affected the power supply and demand. Not only GCC Nations but the entire world is reforming the planning, policies and strategies for their power sectors. The rate of increase in electricity consumption in GCC countries from 2005 to 2009 was $8.87 \%$ (the greatest rate increment was in Oman, 22.6\%, and the smallest in SA, 6.3\%). In order to satisfy this public demand, GCC nation has invested capital to increase their power production by fossil fuels during last few decades. According to the World Energy Council (WEC) the total $\mathrm{CO}_{2}$ emission to the earth by the GCC countries is accumulated not more than 2.25\%; $0.1 \%$ for Bahrain, $0.4 \%$ for UAE, $0.1 \%$ for Oman, 1.2\% for Saudi Arabia, 0.2\% for Qatar and 0.2\% for Kuwait. WEC had an estimate that the GCC countries will require $100 \mathrm{GW}$ of additional power over the next 10 years to meet their ever growing demand.

Gulf countries have already realized that ill affects over their power sector because of this uneven globalization. Now, as earlier discussed that they are planning, making suitable policies and appropriate manufacturing and production strategies, unbundling political barriers towards privatization and appreciating investment in this power sector.

\section{REFERENCES}

[1] B. Petroleum, "BP Statistical Review of World Energy," 2011.

[2] Outlook, “Energy Information Administration,” US Department of Energy, 2010.

[3] D. Allen, "Globalization and Energy Supply: Strategic Risk in the 21st Century,” Deloitte, 2004. http://books.google.com.sa/books?id=LjZqAAAACAAJ

[4] J. Al-Alawi, S. Sud and D. McGillis, "Planning of the Gulf States Interconnection,” IET International Conference on AC and DC Power Transmission, 1991, pp. 38- 
43.

[5] “Electricity Consumption 2009,” 2009. http://www.photius.com/rankings/economy/electricity_co nsumption_2009_0.html

[6] J. Al-Alawi, S. Sud and D. McGillis, "Planning of the Gulf States Interconnection,” WSTA Fourth Gulf Water Conference, Bahrain, 13-18 February 1999, pp. 71-75.

[7] J. Al Alawi, S. Sud and D. McGillis, "Planning and Design of the Gulf States Interconnection," IEEE Power Engineering Review, Vol. 14, No. 12, 1994, pp. 30-34.

[8] J. Al-Alawi, S. Sud and D. McGillis, "Planning of the Gulf States Interconnection,” IEEE, Panel Session: Middle East Policy on Electricity Infrastructure, Interconnections, and Electricity Exchanges, San Franciso, 1994, pp. 24-28.

[9] Karim, N. Maskati and S. Sud, "Status of Gulf Co-Operation Council (gcc) Electricity Grid System Interconnection," Power Engineering Society General Meeting, 2004, pp. 1385-1388.

[10] The GCC Interconnection Authority (GCCIA), "Gccia Grid,” 2011. http://www.gccia.com.sa

[11] E. Woertz, "Alternative Energy Trends and Implications for Gcc Countries,” Gulf Research Center, Dubai, 2008.

[12] KACST, “'An Overview of Kacsts Scientific Activities”.” http://www.kacst.edu.sa/inst/eri/spap.php

[13] F. S. Huraib, "Saudi Arabiar\&D Effort in the Field of Solar Energy.” http://www.un.int/saudiarabia/solar3

[14] S. A. Al-Athel, "Solar Energy in the Kingdom of Saudiarabia.” http://www.un.int/saudiarabia/solar2

[15] “Solar Energy in the Kingdom of Saudiarabia." http://www.un.int/saudiarabia/solar2

[16] S. M. H. F. S. Huraib and S. H. Alawaji, "Solar Energy Projects in Saudiarabia.” http://www.un.int/saudiarabia/solar1.

[17] “Saudi Arabia and Solar Energy a Special Section,” 1981. http://www.saudiaramcoworld.com/issue/198105/saudi.ar abia.and.solar.energy.a.special.section.htm

[18] H. S. Andreas Brinner, "Das deutsch-Saudiara bischetechnologie ent wick lungs program hy solar," International Conference on AC and DC Power Transmission, 1991.
http://www.dlr.de/fk/Portaldata/40/Resources/dokumente/ publikationen/Hysolar_Brinner_2002.pdf

[19] E. Woertz, “The GCC Economies in 2006,” Gulf Research Center, Dubai, 2007.

[20] E. Woertz, “The GCC Economies in 2007,” Gulf Research Center, Dubai, 2008.

[21] Arab News, "Al-Naimi Slams Biofuels, Favours Solar Energy,” 2008. http://www.tradearabia.com/NEWS/OGN_141608.html

[22] Oman Daily Observer, “Oman Eyes Renewable Energy,” GRC Environment Research Bulletin, 2008.

[23] M. A. Raouf and A. Saif, "Renewable Energy in the Arab Gulf States: Current Situation and Prospects,” 2008. http://www.grc.ae/data/contents/uploads/environment_74 12.pdf

[24] Euro Golf Energy Forum, “Kpc Presentation,” Kuwait, 2-3 April2005.

[25] G. A. T. E. GATE, "Catching Solar, Wind and Geothermal Energy. Advising on Renewable Energies in the Mena Region,” 2007.

[26] J. Vidal, "Masdar City: A Glimpse of the Future in the Desert," The Guardian, Vol. 26, 2011.

[27] D. Reiche, "Renewable Energy Policies in the Gulf Countries: A Case Study of the Carbon-Neutral 'Masdar City' in Abu Dhabi,” Energy Policy, Vol. 38 No. 1, 2010, pp. 378-382.

[28] F. Trieb et al., "Concentrating Solar Power for the Mediterranean Region,” DLR, Stuttgart, 2005.

[29] M. Islam, A. Alili, I. Kubo and M. Ohadi, "Measurement of Solar-Energy (Direct Beam Radiation) in Abudhabi, Uae,” Renewable Energy, Vol. 35, No. 2, 2010, pp. 515519.

[30] M. Harris, “The Globalization of Energy Markets,” Challenges of the Global Century, National Defense University, Washington DC, 2001.

[31] H. Scheer, "Energy Autonomy: The Economic, Social and Technological Case for Renewable Energy,” Earthscan, 2007.

[32] A. Correlje and C. Van der Linde, "Energy Supply Security and Geopolitics: A European Perspective,” Energy Policy, Vol. 34, No. 5, 2006, pp. 532-543. 